\title{
How Would a Realist Explain the Civil War in Afghanistan?
}

\section{Amanullah Haidary Azadany, MA}

Istanbul Aydin University, Turkey

\begin{abstract}
This paper is looking to examine Afghanistan's Civil war through core concepts of Realism. Realism holds that civil wars occur when the dichotomy between the domestic order and international chaos breaks down. In such a situation, central government loses its legitimacy and thus people start to own back the liberty that already was given to the central government for sake of security. In Afghanistan, the same dynamics happened. Since 1990s, people lost trust on the governments and thus mobilized around ethnical lines to accumulate power and seek security for them. This paper concludes that partition is the fundamental solution for civil wars like that of Afghanistan.
\end{abstract}

Keywords: Realism, Intra-state wars, Afghanistan, Partition

\section{Introduction}

In order to have a good grasp of the political events that occur everyday around us, it is crucial to know the theories around which the international relations discipline revolves. These theories are like a pair of glasses with different colored lenses, every color lenses shows the same thing in different colors. In the past, to have a comprehensive and clear understanding of the political events, thinkers devised some simplifying means or theories. Realism, Liberalism, Marxism, Social-Constructivism, Post-Structuralism and Post-Colonialism are the main theoretical perspectives they left behind as their immortal legacies for next generations. Among these theories, Realism has been the dominant school of thought, for it provides the most comprehensive and best-developed answer for the most recurring feature of human life, war (Smith, Owens, \& Baylis, 2011, p. 3). Therefore, in this paper as a student of International relations, I would like to apply an exclusive account of realist perspective on causes of civil war in Afghanistan and offer a realist solution for it. The first part of the paper reviews the core concepts of realist thought on international relations and 
more specifically the cause of Intra-State wars. The second part presents some historical background on Intra-state war of Afghanistan. The final part elucidates and analyses Afghanistan's civil war exclusively through realist lenses.

\section{Core Concepts of Realism on Intra-State war}

Realism holds that drive for power and the will to dominate is the fundamental feature of human nature. The negative idea about the human nature, which is believed to be short, nasty and brutal, is providing a clear explanation about the essential features of international politics such as competition, fear, and war. The currency for realism is power. Since states have to accumulate power, state leaders have the duty to calculate rationally different ways in which the state perpetuates in a hostile environment. States leaders are required to distant themselves from the universal moral principles that are usually denoted with positive values of different religious beliefs. Instead, they are required to learn a new set of moral principles, which are in accord to the political necessity and prudence. However, it should be made clear that Realism is not immoral; rather it is moral in a sense that it creates an ethical political community. The dual moral standard system in realism holds that domestically the state has order in which people are bound together by some moral principles and value systems. On the other hand, in outside state is in an anarchic situation in its relations with other states. Killing, lying and cheating might in times be ethical for state in conducting its foreign affairs while domestically such actions would be considered unethical (Dunne \& Schmidt, 2011, p. 86).

Realism as a dominant theory is revolving around three fundamental elements of Statism, Survival and Self-help. Although there are various strands of realism developed in different time intervals, all the different variants of this school of thought share a unified stand on these core sets of concepts. Statism refers to the idea that state rather than transnational organization or non-state actors are the principle actor in international level. State should be sovereign. Sovereignty of state is connected with mobilizing force, since Max Weber definition of states is " a community of people who have monopoly over legitimate use of force in a given territory. State as a main actor begs its legitimacy from the collective desire of people who give up their liberty for security. Michivially a prominent classical realists argue that people sign the social contract directly leaving away their liberty for sake of security which is provided by the legitimate state. Therefore, this contract between people and the state establishes an ordered domestic environment. But, the outside anarchic environment looms and thus states struggle together in seeking power and security. This creates competition and competition for power and security prevails to the very existence nature of 
the state (Dunne \& Schmidt, 2011, p. 93).

In this anarchic international environment, states are obliged to seek initiatives that contribute to their survival. Every state's fundamental national interest is survival. In order to survive in this chaotic international system where there is not an overarching authority, states are required to accumulate power. Power is defines as the man's control over minds and actions of other man. Thus, power in the survival context refers to military, political, economical improvements (Dunne \& Schmidt, 2011, p. 94).

The last element of realism is Self-help, which refers to the principle of action in anarchical system. Lack of higher authority above states in the international system indicates that it is the state itself rather than any transnational institution or any non-state actor on which states can rely for their security. Security can only be realized through self-help. According to realism, quest for security of one state is another state's source of insecurity. Therefore, states continue to threaten each other by simply transcending them in developing more advanced military equipment, having more stable political system and the like. Some states may transcend the power of others, in order to keep up the balance of power; weak states enter into alliances where the power of their newly formed alliance equals the power of the strong states and thus increase the security of all (Dunne \& Schmidt, 2011, p. 95).

\section{Background on Afghanistan's Intra-State war}

Having in mind these core concepts of realist thought on international relations, now I would like to explore some of the latest development in Afghanistan's history so that I possibly apply the above concepts on Afghanistan war. Afghanistan was one of the battlefields of cold war where two superpowers USA and USSR were waging their proxy wars from 1979 to1989. US money, which flowed to region to light the fire of anticommunism sentiment, contributed largely to establishment of Islamic radicalism throughout Afghanistan Pakistan frontiers. At inception, these US-created guerrilla fighters proved useful in pursuing the interest of USA in the region. The Mujahedin who were called freedom fighters appeared as formidable force against the red army of Soviet Union and the Sovietbacked-Afghan government. With collapse of Soviet Union in 1989, USA triumphed over the USSR and thus Afghanistan lost its political and economical significance to USA (Coll, 2009, pp. 420-425).

USA and USSR which emerged as two superpowers at the end of Second World War, immediately started to enter into a cold war, where this time their battlefield was not mainly Europe but also a couple of Asian countries. The fundamental difference between USA and USSR was their unique and separate presumptions about adopting a different international 
society. USA along with its war torn allies of European states were advocating for an adoption of an international society which was based on elements, such as sovereignty, non intervention, international law, balance of power and institutions for diplomacy. On the other hand, USSR was supporting for a type of international society, which was based on the communist values. At the end of cold war, European type of international society prevailed over the collapsed USSR preferred international society. This political event changed the order of international system where instead of previously like bipolar system, unipolarity emerged. In this unipolar system, USA appeared as the hyper-power where no other state was in USA level to compete with. With lack of a strong opponent to compete with, USA became reluctant about events that occurred near or at far during 1989-2001 (Armstrong, 2011, pp. 34-38).

Afghanistan was one of the main victims, where previously during the cold war, it was the main focus for American diplomats. Torn into pieces and tired of one-decade fatal war, Afghanistan was abandoned and left in hands of Pakistan to be taken care by. Pakistan empowered a newly formed Islamic radical faction, Taliban, where they cruelly and inhumanly governed Afghanistan. The Islamic radical government of Afghanistan shared some traits with terrorists groups and the Arab terrorists soon harbored Afghanistan where they openly built training camps for training their operatives inside the country and threatening the west (Coll, 2009, pp. 9899). After the attack of $9 / 11$ on world trading centers, the international community forces in campaign of war on terror occupied Afghanistan. Taliban appeared to be defeated at first years of military intervention, but since 2005 they started to reappear as a formidable force fighting against the foreign troops presence in the country. The guerrilla fighters who used to be called Freedom Fighters are now called the terrorists and insurgents (Barfield, 2010, pp. 74-80).

\section{Analysis of Realist Thought on Afghanistan's Intra-State war}

Now I would like to apply the above theoretical concepts of realism on the issue of civil war in Afghanistan since 1990s. Realism holds that when the sovereign authority of a state collapses, intra state wars (civil wars) happen for many the same reasons that wars between states happen. According to realism, wars between states happen because the international system is anarchic and thus every state seeks more power and security. When there is not a sovereign authority, to which the people already gave up their liberty in exchange of security, people refrain more from giving up their liberty. Instead, they find a group with whom they share some traits, values or ideologies, and with this the state divides between different groups based on ethnic, religious, and political lines (Dunne \& Schmidt, 2011, p. 88). 
The collapse of Soviet-supported Afghan communist regime in 1992 marks the collapse of a sovereign authority in Afghanistan. The Mujahedin rule (1992-1994) and Taliban rule (1993-2001) were embodied with continual fighting fueled on ethnical and religious lines. The four dominant ethnic groups Pashtuns, Tajiks Hazara and Uzbeks were divided into separate political and ethical factions and thus each seeking power and security. This domestic situation of continual fighting and violence is similar to the anarchic environment of international system. For the same reason that states pursue power and security in international system, during the Intra State war, Afghan people for sake of guaranteeing their security sought more power. This struggle for powers resulted in pervasive internal conflicts. In Afghanistan, people were mobilized around the ethnic lines to seek power and security. Hazara minorities were subjected to violent suppression and use of brutal force against them during Taliban regime (Saikal, 2010, pp. 100-102). Therefore as a whole, a realist would argue that during a civil war like that of Afghanistan, different groups inside the state will vie for power in an attempt to gain sense of security (Saikal, 2010, pp. 40-48).

The same concept of security dilemma of Inter-state war explains similar political dynamics of an Intera-State war. During civil war, it is natural when different ethnic, religious, and social groups suddenly find themselves responsible for their own security. It is also natural to find that for these groups, security is the priority and that they seek every means to perpetuate their own existence. Just as in case of inter state war, the quest of security for one state is a source of insecurity for another. The way that Jamiat-e Islamic party of Afghanistan dominated by Tajiks was hostilely unfriended by Hezb-e Islamic party dominated by Pushtoons on power sharing during 1990s, for example, indicates the uncertain and mistrust condition of domestic realm, when the legitimate authority breaks down. This was largely due to the fact that each of these ethnically divided parties aimed to seek more power and security (Gall, 2014, pp. 209-212). Still in 2015 presidential elections, the formation of Afghan Unity Government posed this concept of competition for maximizing power among different ethnical groups. The fraudulent presidential election of 2015 failed to help transfer peacefully the power from one legitimate authority to another (Ruttig \& Qanne, 2014).

A Realist would suggest that the solution for Afghanistan and for other similar civil wars is separation or partition (Dunne \& Schmidt, 2011, p. 88). Unlike many liberal solutions to civil and ethnic wars that rest on power sharing agreement and the creation of multi-ethnic states, realists advocate for partition. From a realist perspective, the political agreement which is concluded at the end of fraudulent presidential election is that not contributing toward peace and sustainability, but also it is widening the 
divides more among different factions in the country. Realists would be skeptical of the basic cornerstones for establishing a government based on powering sharing in Bonn Conference in 2001.They would argue that societies which have been torn and entered into war on ethnic and religious lines are best cured when they are separated. Realists buy the idea that creating a central government can eliminate domestic anarchy. They also argue that while the creation of multi ethnic state might be a notable endeavor, they don't have a very good success rate. From the inception in 2001, the newly established Afghan state was sharing power along regional and ethnic lines. Among all the ethnicities, Pushtoons have been dominating the Afghan political scene especially in the last decades when the Taliban brutal regime, Pushtoons occupying a major bulk, was made up. Therefore, with this type of uneven distribution of power, the tension is high in level. This uncertain and mistrustful environment where one dominant ethnical faction owns the politics of the country and it has used any sources of violent force to suppress other power contesters, has created more chaos and disorder inside the country (Barfield, 2010, pp. 207-210).

A realist would argue that with collapse of the legitimate authority of Afghanistan in 1992, people got back their liberty to acquire their security themselves. Therefore, it is rational for them to mobilize around ethnical or religious factions to seek power and security domestically exactly the same as states normally in anarchic international system do. Dominant ethnic groups like Pusthoons were compelled to acquire more power and to dominate others to preserve their rule they had acquired. At the same time, the suppressed and marginalized ethnical groups like Hazaras, Uzbeks were equally compelled by necessity to go to war in order to forestall being vanquished by Pushtoons. This scenario suggests, that this situation of domestic anarchy prevails unless the country is separated among the dominant ethnical lines where the central governments of each newly established states would again receive legitimacy and thus acquire the monopoly over legitimate use of force in their given territories (Dunne \& Schmidt, 2011, p. 88).

\section{Conclusion:}

Realism as a dominant theory of international relation observes state as the main actor in international system. Unlike other international relations theories of Liberalism, Marxism, Realism hold that with collapse of the legitimate authority in a state, the dichotomy between ordered domestic sphere and anarchic international system breakdown. This breakdown of the dichotomy between domestic and international sphere, changes the formula in a way that the former domestic sphere like the international system becomes disordered. In such disordered environment, the individuals take 
back their liberty they previously gave up to state for sake of their security. Now that state loses its legitimacy, individuals mobilize around ethnic, religious and social lines to seek power and security. In case of Afghanistan after collapse of legitimate authority of state in 1992, Afghans have mobilized around ethnical lines to seek power and security. Mobilization of Afghans on different ethnical lines created competition for power and security among the different factions, this competition is analogous to the type of competition which is common among the states in the anarchic international system. Therefore, domestic sphere in Afghanistan during civil war was mistrustful and this mistrust prevails until now that Taliban didn't give up their arms and fighting. Since this, mistrust among multi ethnic groups continues, a realist would suggest separation as the fundamental cure for replacing the disordered domestic sphere to a ordered domestic one. Creation of central governments for the separated Afghan states would eliminate the domestic anarchy and thus created organizational hierarchy where newly ethical political communities emerge.

\section{References:}

Armstrong, D. (2011). The Evolution of International Society. In J. Baylis, S. Smith, \& P. Owens, The Globalization of World Politics (pp. 34-38). Oxford, UK: Oxford University Press.

Barfield, T. (2010). Afghanistan: A Cultural and Political History. Princeton, UK.

Coll, S. (2009). Ghost War: The Secret History of CIA, Afghanistan and Bin laden from Soviet invassion to September 10 2011. Newyork: NDF press.

Dunne, T., \& Schmidt, B. (2011). Realism. In J. Baylis, S. Smith , \& P. Owens, The Globalization of World Politics (p. 86). Oxford, UK: Oxford University Press.

Gall, C. (2014). The Wrong Enemy: America in Afghanistan, 2001-2014. NewYork: BIT Press.

Ruttig, T., \& Qanne, E. (2014, 11 19). After the Election is Before the Elections: The Dilemma with the 2015 Parliamentary vote date. Retrieved 02 12, 2016, from Afghanistan Analysis Network: https://www.afghanistananalysts.org/after-the-election-is-before-the-election-the-dilemma-with-the2015-parliamentary-vote-date/

Saikal, A. (2010). Modern Afghanistan: A History of Struggle and Survival. NewYork, USA.

Smith, S., Owens, P., \& Baylis, J. (2011). The Globalization of World Politics: An Introduction to International Relations. Oxford: Oxford University Press. 